Review

\title{
Transformation of Lignocellulosic Biomass into Sustainable Biofuels: Major Challenges and Bioprocessing Technologies
}

\author{
${ }^{1}$ Tahira Naz, ${ }^{1}$ Yusuf Nazir, ${ }^{1}$ Abu Bakr Ahmad Fazili, ${ }^{1}$ Kiren Mustafa, ${ }^{2}$ Xueyuan Bai and ${ }^{1}$ Yuanda Song \\ ${ }^{1}$ Colin Ratledge Center for Microbial Lipids, School of Agricultural Engineering and Food Science, Shandong University of \\ Technology, Zibo 255000, China \\ ${ }^{2}$ School of Agricultural Engineering and Food Science, Shandong University of Technology, Zibo 255000, China
}

\author{
Article history \\ Received: 26-04-2020 \\ Revised: 23-06-2020 \\ Accepted: 06-07-2020 \\ Corresponding Author: \\ Yuanda Song \\ Colin Ratledge Center for \\ Microbial Lipids, School of \\ Agricultural Engineering and \\ Food Science, Shandong \\ University of Technology, Zibo \\ 255000, China \\ Email: ysong@sdut.edu.cn
}

+ Both authors contributed equally to the work

\begin{abstract}
Commercial-scale production of biofuels has recently been intensified due to its cost-effectiveness, sustainability, market stability, alternative fuel energy composition and greener output, etc. Lignocellulosic biomass attracted the attention of researchers as a renewable feedstock for fermentative conversion into biofuels because of its high productivity, low agricultural input requirements, being environmentally friendly and no competition with the food crops. The field of bioenergy is rapidly evolving with discoveries that are being reported daily. In this review, the economical production of biofuels using different feedstocks and bioprocessing strategies with the aim of integral utilization of agricultural or organic wastes are discussed. This review also highlights the potential of pyrolytic oil as fermentable substrates for different types of microbes (yeast, bacteria and algae) to generate biofuels. Although there is continuous technologic improvement for cost reduction in biomass conversion by microbial fermentation. Still, there are many techno-economic challenges such as recalcitrant nature of substrates, removal of inhibitors, metabolic engineering of microbial strains and detoxification strategies for the elimination of inhibitors. So, this review also summarizes some of these major challenges that should be addressed to make biofuel production cost effective.
\end{abstract}

Keywords: Biofuel, Lignocellulosic Biomass, Pyrolytic Oil, Major Challenges

\section{Introduction}

Fuel has been playing a significant role in the development of the economy of most countries for a long time. Currently, major energy demands $(80 \%)$ are fulfilled with petroleum resources and chemical fuels, especially in the transportation and industrial sectors (Gaurav et al., 2017). It has been reported that $95-97 \%$ of global bioenergy is produced through direct combustion of biomass, resulting in the production of a higher amount of ash on the ground and in the air, which restricted its application (Vassilev and Vassileva, 2016). Increased demand for petroleum-based fuel has led to the exhaustion of fossil fuel reserves and caused an increase in the price of mineral-based fuels such as petroleum, diesel, kerosene, natural gas. The main reasons for the rapid depletion of energy sources are the rapid growth of the human population and industrialization globally (Lam et al., 2010). Also, extensive usage of this fuel is found to have a significant contribution to the emission of harmful gases, resulted in tremendous adverse effects such as receding of glaciers, loss of biodiversity, climate changes, rise in sea level, etc. Global protection of the environment is of urgent concern due to greenhouse gases that can be addressed by avoiding the use of petroleum-based fuels and emissions of harmful smoke from vehicles. Moreover, with increasing human population and exhausting fossil fuel-based energy sources, energy protection has also become a global issue in recent years. Therefore, there was an urgent need to explore a greener alternative source of energy, leading towards extensive research on bio-based fuel, also known as biofuels, which have gained considerable attention over the past few decades (Mishra, 2018).

There are several types of biofuels, which include liquid biofuels (biodiesel, bio-oil, bioethanol, biobutanol, biomethanol), gaseous biofuels (biohydrogen, biogas, biomethane), solid biofuels (biochars) and biomass biofuels (Demirbas, 2008; Guldhe et al., 2017). Biofuels 
are classified into first, second, or third-generation depending upon the feedstock used (Guldhe et al., 2017; Malik et al., 2015). First-generation biofuels that are more frequently available in the market are produced from a variety of food crops such as canola, corn, soya beans and other vegetable oil. But increased consumption of the first-generation biofuel showed several drawbacks, including competition with food resources, an increase in price for feed commodities and requirement of colossal area for crop plantation, giving rise to food versus fuel debates. Therefore, a possible solution for these problems is the second-generation biofuels (Zanotti et al., 2016). Second-generation biofuels can be produced from a variety of non-edible lignocellulosic feedstock, including agricultural and forestry residues, wood, energy crops and municipal waste (Guldhe et al., 2017; Sannigrahi and Ragauskas, 2011). Second-generation biofuels can avoid competing for food crops for productive land with no significant impact on the environment. Bioethanol production has attracted special attention among other liquid biofuels, particularly in the USA, Europe, Brazil and few Asian countries. One liter of ethanol has $66 \%$ more energy than one liter of petrol (Nigam and Singh, 2011).

Third-generation biofuels that are produced from algae have gained popularity recently mainly due to $20-80 \%$ (dry weight) lipid accumulation in their cells (Singh et al., 2016), no competition with food, the high biomass production per hectare of cultivation and strong absorption of $\mathrm{CO}_{2}$ (Batista et al., 2018). It can generate biohydrogen, biomethane and bioethanol. Biodiesel can be produced from oil extracted, while lipids extracted algal cell bodies can be used for the generation of biomethane and bioethanol (Singh et al., 2015). However, commercial-scale production of algal biofuel is still in the early stages (Guldhe et al., 2017) due to its higher cultivation and production cost. Algal biofuel production could cost exceed $30 \mathrm{USD} /$ gallon sometime while the highest price of gasoline was reported as 4.11 USD per gallon by the U.S Energy Information Administration (https://futureofworking.com/7advantages-and-disadvantages-of-algae-

biofuel/).Another drawback of microalgal derived bio-oil is its less stability as compared to other approaches due to different polyunsaturated fatty acid content of microalgal oil (Burton et al., 2009). Microalgal unsaturated fatty acids include fatty acids of nutritional importance such as EPA (eicosapentaenoic) (20:5) acid and DHA docosahexaenoic acid (C22:6) which are not present in vegetables (Breuer et al., 2012) and susceptible to oxidation and peroxidation particularly by reactive oxygen species (Nazir et al., 2020). Moreover, it has been reported that high oxidative stability of algal biooil was lost entirely after the removal of tocopherol and other antioxidants through chromatographic purification
(Frankel et al., 2002). These antioxidants, occurring naturally in microalgae, were proposed to protect these unsaturated fatty acids from oxidation (Ryckebosch et al., 2012). These pieces of evidence denied the claims that DHA rich algal oil is unusually stable to oxidation.

Conversion of lignocellulose biomass into biofuel offers significant advantages to the environment. As tons of biomass generated from industry, forest, agricultural, marine and urban solid waste is decaying with uncontrolled mechanisms and leading to environmental concerns by unpredictable toxic gas emission. A variety of renewable sources such as commercial energy crops, forest and agricultural residues, organic municipal solid waste, demolition, wood, or used cooking oils are considered as rich natural resources for biofuel production. Due to environmental concerns, the share of biofuels in the automobiles market will grow more rapidly in coming future, leading to strong growth in agricultural sectors for increased biofuel production and associated by-products (Gaurav et al., 2017). Because of all these reasons, rapid biofuel intensification from lignocellulosic biomass has occurred in recent few decades, which is discussed briefly in this review.

In spite of all the benefits, the production of biofuel from the lignocellulosic biomass faces tremendous challenges for its sustainable development. Therefore, this review aimed to highlight the utilization of biomass to produce biofuel economically, with the integral usage of agroindustry lignocellulosic biomass in general and pyrolytic oil generated from major agriculture waste resources in detail. Pyrolytic sugars and organic acids are of particular interest for biofuel producers because it can be utilized as carbon sources by microorganisms to generate biofuels. As the study on the microbial conversion of pyrolytic oil to generate energy is a less explored area of biofuel research and little is known about its economic separations, neutralization, hydrolysis, detoxification and fermentation of sugars and acetic acid present in pyrolysis oil. So, this review also focuses on some applicable pretreatment and detoxification strategies to get clean fermentable substrates for microbial fermentation. Furthermore, bioprocessing technologies for biomass conversion and the main challenges of biofuel production with an aim to replace fossil fuels are also discussed.

\section{Driving Forces for Intensification of Biofuels from Biomass}

Biomass can be defined as a natural and inexpensive form of energy storage that can be utilized at any time (Rajesh et al., 2008). Biomass has been reported as the fourth largest available energy resource of the world (Haykiri-Acma and Yaman, 2010). According to the statistics released by the WBA (2017), billions of tons of 
renewable biomass are produced globally, of which India, Brazil and Indonesia are recognized as major contributors (WBA, 2017). For example, the current annual availability of biomass, which includes agricultural and forest biomass in India, is estimated to be around 500 million metric tons (Gaurav et al., 2017). Without proper management, these tons of biomass would decay with uncontrolled mechanism, leading to environmental problems such as unpredictable toxic gas emission and more (Gaurav et al., 2017; Haykiri-Acma and Yaman, 2010). Therefore, researchers are finding effective ways to grasp the potential energy available in the biomass through the mechanism of energy transfer.

Energy is a crucial driving component of the economy. Every region has its own local renewable energy resources, which reduce the dependency on oil imports and ensure the increasing supply of feedstock. Currently, $14 \%$ of the global energy demand is fulfilled by bioenergy from biomass (Guldhe et al., 2017). One of the significant advantages of biofuel production is that it can be produced from biomass either by direct conversion or with the aid of microbial fermentation technologies (Wainaina et al., 2018). Current biofuel policies are aimed to promote the use of biomass-based fuels for transportation purposes as well as providing new economic opportunities for people, especially in rural areas, majorly from agricultural feedstocks. The biomass intensive future energy supply scenario included 385 million hectares of biomass energy plantations globally in 2050, with three-quarters of this area established in developing countries (Kartha and Larson, 2000). The increase in energy consumption with limited availability of petroleum resources has aroused huge concern about the sustainability of our society and way of life. Producing renewable fuels is one of the ways to mitigate the potential for an energy crisis and, therefore, has raised the need for extensive research to find alternative fuels to replace chemical fossil fuels (Azad et al., 2014). This phenomenon has led to a significant increase in biofuel productions. For example, in only one-decade biofuel production augmented from 20 billion liters to more than 110 billion liters from 2001-2011 (Esterhuizen, 2013), mainly bioethanol and biodiesel production. One survey conducted by US Environmental Protection Agency (EPA) in 2010 reported that by 2021, biofuel production is expected to reach 222 billion liters with bioethanol and biodiesel contribution of almost 19 and 81\%, respectively (EPA, 2010). It was also reported that biodiesel obtained from grease waste and soya oil could reduce GHG emission by 87 and $57 \%$, respectively, as compared to petroleum diesel (Sissine, 2010). Following the research of the International Energy Agency (IEA), by 2050, biofuel could contribute about $27 \%$ of the total transportation fuel (Pandey et al., 2016). The expected use of biofuels has the potential to avoid $\mathrm{CO}_{2}$ emission (2.1 giga tons/year) into the atmosphere if production sustainability is maintained (Fairley, 2011).

\section{Approaches for Biomass Conversion}

Generally, there are two most common techniques for biomass conversion; thermochemical and biochemical/biological conversion. In thermochemical conversion, heat is employed with increased pressure to denature biomass and chemical catalysts are used to synthesize chemicals and fuels while in biochemical conversion, enzymes are used to degrade biomass to obtain products (Liew et al., 2016; Wainaina et al., 2018).



Fig. 1: Overview of thermochemical, biological conversion and hybrid conversion 
There is also a third type of conversion known as hybrid conversion, which employs both thermochemical and biochemical conversion (Shen et al., 2015). Figure 1 depicts the general overview of these approaches. Hybrid processing employs thermal decomposition of biomass to produce substrates, which can be used to produce fuels and other useful compounds after being metabolized by microorganisms. It includes two pathways to produce fuel: Syngas and bio-oil fermentation. Till now techno-economic viability of syngas production is widely studied as compared to biooil fermentation based on fast pyrolysis by hybrid processing (Claypool and Simmons, 2016; Munasinghe and Khanal, 2010). It indicates an exceptional opportunity for lignocellulosic biomass conversion as it alleviates some of the shortcomings of traditional thermochemical and biochemical (pretreatment, hydrolysis, fermentation) processing. Thermochemical conversion of lignocellulosic biomass by pyrolysis readily overcomes recalcitrant nature of biomass, while biological utilization of the pyrolysate provides high product selectivity (Jarboe et al., 2011). Above all, it has the potential to produce inexpensive fermentation substrate than enzymatic hydrolysis which requires costly enzyme cocktail (Shen et al., 2015).

\section{Biomass Feedstocks}

The selection of biomass feedstock is one of the important criteria to produce high quality and sustainable biofuel. According to previously published researches, selected feedstock must be high in energy content, easily available in large quantities and be amenable to the conversion processes (Kraiphanont et al., 2016; Wang et al., 2016). Renewable sources of biomass feedstocks for energy production include agriculture crops, agricultural and forest residues and other organic waste sources, e.g., organic municipal solid waste, demolition, wood, or used cooking oils (Guldhe et al., 2017). Recently algal biomass has also attracted attention as a future feedstock for advanced biodiesel production because microalgal biomass can produce more than one biofuel in an integrated biorefinery. Different biomass feedstocks are shown in Fig. 2.

Lignocellulosic mass consists of three types of polymers; cellulose (35-55\%), hemicelluloses (20-40\%) and lignin (10-25\%), all of which are chemically bonded and strongly intermeshed (Wei et al., 2015). Cellulose (consisting of D-glucose only), hemicelluloses (consisting of pentose, xylose, arabinose) and hexoses (containing mannose, glucose, galactose) are bio convertible (Galbe and Zacchi, 2012). Decomposition of pure cellulose occurs between $300-430^{\circ} \mathrm{C}$ to form char, non-condensable gas and anhydrosugar intermediates predominantly levoglucosan (Mohan et al., 2006). Other products include a variety of furans, aldehydes, ketones and acids that can either be directly produced from cellulose (Patwardhan et al., 2011) or by secondary reactions such as polymerization, dehydration, radical recombination and trans glycosylation (Antal, 1983).

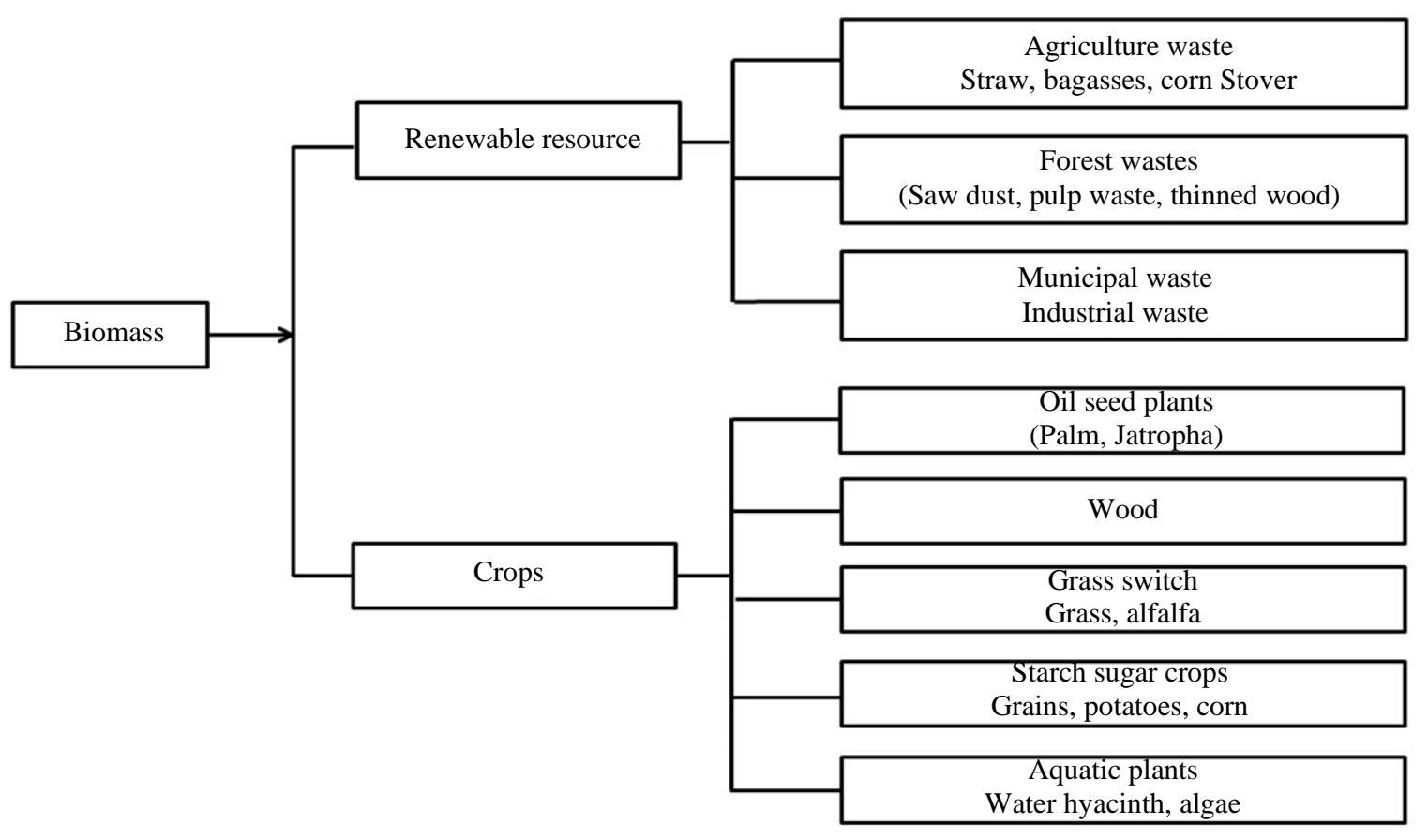

Fig. 2: Biomass as renewable feed stock for biofuel production (Naik et al., 2010) 
Biofuel production from lignocellulose involves an integrated process consisting of three basic steps: Pretreatment, hydrolysis and fermentation (Ojeda et al., 2011). Pretreatment (milling and alkali, acidic or enzymatic treatments) of lignocellulosic biomass is necessary for the effective utilization of these carbon sources by biofuel-producing microorganisms. Therefore, many researchers around the world are working on the development of possible biomass integrated conversion and pretreatment technologies. It has been estimated that the pretreatment process contributed nearly $20 \%$ to the overall conversion costs for different products (Seidl and Goulart, 2016). Pretreatment resulted in disruption of the lignin seal to make holocellulose accessible for the hydrolytic enzyme, reduction of cellulose crystalline structure, improved surface area and porosity of pretreated biomass, which in turn increased the rate of hydrolysis (Bensah and Mensah, 2013).

Commonly two methods are used for pretreatment of lignocellulosic biomass, i.e., chemical and biological pretreatment. The selection of a particular pretreatment method depends on the lignocellulose biomass being used as the composition of each biomass vary (Dahadha et al., 2017). Chemical pretreatment includes biomass hydrolysis using alkali, acid and ozone. Temperature, retention time and concentration of acid are the most crucial factors for the efficiency of acid hydrolysis. Li et al., successfully generated bioethanol by carrying out the pretreatment of Municipal Solid Waste (MSW) by dilute acid $\mathrm{H}_{2} \mathrm{SO}_{4}$, $\mathrm{HNO}_{3}$ and $\mathrm{HCl}$ and found that yield of glucose depends more on the concentration of acid and enzyme as compared to reaction temperature (Li et al., 2007).

Similarly, Patra et al., investigated different pretreatment methods and found that the highest ethanol yield was achieved with alkali-treated biomass, followed by enzymatic hydrolysis with Aspergillus niger. They observed that alkali pretreated MSW produced more sugar as compared to acid-treated (Patra et al., 2017). Shetty et al., used alkaline pretreatment for biomethane production from rice straw and found that $1 \% \mathrm{NaOH}$ was efficient enough to reduce lignin and hemicellulose content while cellulose content remained unchanged. They obtained $34 \%$ more methane for treated straw in comparison to untreated rice straw (Shetty et al., 2017). Calcium hydroxide, known as lime, was also used for alkaline pretreatment and has been reported as a simple and effective pretreatment method due to the less cost of $\mathrm{Ca}(\mathrm{OH})_{2}$ and safety concerns. Pretreatment of corn cob using lime increased the biogas production two-folds times as compared to untreated corn cob because pretreatment expedites the anaerobic digestion by delignification (Shah and Tabassum, 2018).

Biological pretreatment involves the utilization of enzymes obtained from bacteria and fungus that can degrade complex lignocellulosic biomass into simple sugars. Biological pretreatment is a time-consuming process, yet it has the advantage of greater efficiency and less energy consumption in the process. Enzymatic hydrolysis, the efficient pretreatment method, uses cellulase or hemicellulases with benefits of substrates specificity, less toxicity, no inhibitor formation and cost-effectiveness (Ferreira et al., 2009). The pretreated saccharified lignocellulosic biomass is followed by microbial fermentation with various bioethanol-producing microorganisms. Furthermore, many studies showed pretreated biomass produced a higher yield of biohydrogen than untreated biomass and it was also observed that the biologically treated biomass produced a higher amount of biohydrogen (Reginatto and Antônio, 2015).

Some of the renewable biomass from agriculture sectors used for biofuel production are discussed below and presented in Table 1.

Table 1: Biofuel production through commonly available agricultural by-products






\section{Rice Straw}

Rice straw is one of the most important and abundant lignocellulosic feedstocks throughout the world, especially in Africa and Asia. About 667.6 million tons of rice straw is produced after harvesting in Asia annually. Commonly this massive biomass waste is used as cattle feed and most of it is disposed of in an open field by burning practices that is hazardous for the environment. Rice straw has a typical composition of cellulose in the range of 30-45\%, hemicellulose $20-25 \%$ and lignin is in range of $15-20 \%$ and contains many small organic molecules and ash in a large amount (Bakker et al., 2013). Being rich in sugars, rice straw can be easily converted to biofuel with the aid of fermentation technologies, instead of just wasting. Biobutanol was successfully produced from rice straw by mixed bacterial microflora mainly Clostridial species that were isolated from hydrogen-producing sewage sludge by Cheng et al. The maximum butanol concentration, productivity and yield by using Rice Straw Hydrolysate (RSH) was $2.93 \mathrm{~g} / \mathrm{L}, 0.86 \mathrm{~g} / \mathrm{L} \mathrm{d}$ and $0.49 \mathrm{~mol}$ butanol per mol of reducing sugar, respectively (Cheng et al., 2012).

Similarly, Azad et al., chose the abundantly available rice straw as a fermentation substrate for the economical production of biodiesel by oleaginous yeast, Lipomyces starkeyi. Fermentation of RSH prepared with $3.5 \%$ $\mathrm{H}_{2} \mathrm{SO}_{4}$ at optimum $\mathrm{pH}$ without any detoxification treatment produced the highest amount of biomass, i.e., $12 \mathrm{~g} / \mathrm{L}$ and lipid content of $36 \%$. The fatty acid composition of this microbial lipid was like that of vegetable oils. Their findings concluded that rice straw could be an economical alternate feedstock for biodiesel production by L. starkeyi (Azad et al., 2014). Furthermore, rice straw has also shown the potential to produce 205 billion liters bioethanol per year in the world, which is around 5\% of total bioethanol demand from a single biomass feedstock (Belal, 2013). Recently Takano and Hoshino (2018) produced $30.5 \mathrm{~g} / \mathrm{L}$ ethanol from alkali-treated $100 \mathrm{~g} / \mathrm{L}$ rice straw, resulting in increased sugar content from 56.3 to $80 \%$ by $M$. circinelloides under aerobic condition.

\section{Coconut Waste}

Coconut waste is by-product produced by the cultivation and processing of coconuts. Coconuts are produced by 92 countries on more than 10 million hectares worldwide. The total world production of coconut has been reported as 250-300 million tons (Obeng et al., 2020), while coconut husk production has been estimated as 23 million tons globally (Clarence, 2016). Philippines, India and Indonesia are categorized as major producers of coconut, which accounts for nearly $75 \%$ of whole world production with Indonesia as the largest producer of coconut (https://www.bioenergyconsult.com/coconut-biomass/). Waste biomass of coconut has been recognized as another potential source for bioethanol-based biofuel. After removing the inner part of the coconut, green coconut shell, mature coconut fiber and mature coconut shell can be remarkable substrates for bioethanol production. Mature coconut husk contains $30.47 \%$ of cellulose, $25.42 \%$ of hemicellulose and higher lignin content of $33.15 \%$ of dry weight (Gonçalves et al., 2014). Commonly coconut residues are rich in sugar and with natural fermentation, it is possible to convert it into a high amount of bioethanol. Experiments for commercial production of ethanol from coconut wastes were conducted and the maximum yield of bioethanol $90.09 \%$ and productivity of $0.21 \mathrm{~g} / \mathrm{L} / \mathrm{h}$ was obtained from green coconut shell by Saccharomyces cerevisiae fermentation (Gonçalves et al., 2015). Since coconut husk has been discarded in high volumes (contributed as $80-85 \%$ of the weight of fruit) so if it could be used for secondgeneration ethanol production, it will eliminate the environmental impact due to waste generation and burning process (Bolivar-Telleria et al., 2018). Coconut shell has shown more potential for pyrolysis due to lower ash content, high volatile matter content and availability as a cheap substrate. Sulaiman et al., investigated the possibility of coconut waste to produce biodiesel in situ. They used methanol and $\mathrm{KOH}$ pretreatment. As coconut may contain 10-15\% extractable oil and its Fatty Acid Methyl Esters (FAME) contains C:8-C:12, so it has been regarded as a good source for methyl esters production to produce biodiesel. They obtained the highest yield, such as $64 \%$, by using $5 \%$ of $\mathrm{KOH}$ by mixing raw material and methanol (Sulaiman et al., 2010). Sangkharak et al., produced both biodiesel and bioethanol in two steps from the coconut meal. Firstly, biodiesel was produced from oil of coconut meals and then ethanol was produced using coconut waste generated after extraction of oil as the sole carbon source by S. cerevisiae (Sangkharak et al., 2019).

\section{Wheat Straw}

Wheat straw is another abundantly available feedstock in a larger part of the world that can be used for economic bioethanol production as it contains a blend of sugars. Wheat straw contains $32-49 \%$ of cellulose, $23-39 \%$ of hemicellulose with a lower lignin content of 5-19\% (Gaurav et al., 2017). Wheat straw has a global annual production of 529 million tons (Mata and Savoie, 2005), of which about 400 million tons of wheat straw may be used for the production of biofuel worldwide (Tishler et al., 2015). Many researchers studied the production of ethanol from wheat straw hydrolysate (Klinke et al., 2003; Nigam, 2001; Talebnia et al., 2010). In one such study, Ali et al., used treated wheat straw with different concentrations of perchloric acid in two-step hydrolysis to convert hydrolysate into fermentable sugars. The fermentability of hydrolysate was conducted by a monoculture of 
baker's yeast and a co-culture of baker's yeast with Pichia stipitis. The highest ethanol production was obtained by using co-culture compared to monoculture, i.e., $11.42 \mathrm{~g} / \mathrm{L}$ of ethanol with a yield of $0.475 \mathrm{~g} / \mathrm{g}$, the productivity of $0.272 \mathrm{~g} / \mathrm{L}$. Their study concluded that two-stage hydrolysis and utilization of co-culture were efficient methods for the enhanced production of ethanol (Ali et al., 2012). In the same way, Smuga-Kogut et al., reported that the removal of lignin by pretreating wheat straw increased the ethanol yield significantly using $S$. cerevisiae. Lignin is a main limiting factor in the alcoholic fermentation of wheat straw. Delignification improved the fermentation ability of yeast by eliminating lignin's negative effects on the viability and growth of yeast cells. Chemical treatment with a mixture of $\mathrm{HNO}_{3}$ and ethanol (4:1) resulted in higher concentrations of reducing sugar and ethanol $\left(4.09 \mathrm{~g} / \mathrm{dm}^{-3}\right)$ as compared to untreated lignin-containing straw $\left(1.23 \mathrm{~g} / \mathrm{dm}^{-3)}\right.$. Removal of lignin from wheat straw enhanced glucose concentration almost 4 folds ( $0.4 \mathrm{~g}$ per $1 \mathrm{~g}$ of dry matter) compared to unprocessed wheat straw $(0.1 \mathrm{~g}$ per $1 \mathrm{~g}$ of dry matter) with increased efficiency (Smuga-Kogut et al., 2015).

Karlsson et al. (2016), generated a prospective system for combined biogas and biodiesel (FAME) production from wheat straw using oleaginous yeasts, while investigating a technical process and it's mass and energy balances. Recently Qi et al. (2019), used modified enzymatically treated wheat straw by Clostridium acetobutylicum, producing biobutanol in a concentration of $12.4 \mathrm{~g} / \mathrm{L}$ in Acetone-Butanol-Ethanol fermentation (ABE) with $100 \mathrm{~g}$ yield of $\mathrm{ABE}$ per $\mathrm{kg}$ of wheat straw used. Similarly, biobutanol is more recently produced by simultaneous hydrolysis of chicken feathers and wheat straw, yielding $4.6 \mathrm{~g} / \mathrm{L}$ of butanol by Clostridium beijerinckii strain NCIMB 8052 (Branska et al., 2020).

\section{Corn Stover}

Corn stover is another potential biofuel feedstock for various reasons, e.g., feedstocks uniformity, low production cost and feasibility of production in large quantities. It is also one of the most abundant agricultural residues in the US, Europe and China. 5\% weight of corn is freely available as corn stover that can be used for biodiesel production (Ranisau et al., 2017). The supply of corn stover has been estimated at 75 million tons per year, with the expectation to increase to170 million tons in the future (Hess et al., 2009). Corn stover normally contains $31-41 \%$ cellulose, 20$34 \%$ of hemicellulose, $16-23 \%$ lignin content with $2.4 \%$ ash and $17.4 \%$ extractives (Liu et al., 2013). Corn stover is a readily available feedstock for biorefineries, being the most abundant crop residue in the US. Li et al., investigated corn stover as an agricultural by-product for bioethanol production and successfully produced ethanol in a concentration of $22.3 \mathrm{~g} / \mathrm{L}$ by pretreatment of sugar-rich corn stover via Two-step Simultaneous Saccharification and Fermentation (TPSSF). In the first step recombinant strain, Escherichia coli KO11 was used for pentose conversion followed by the second phase in which $S$. cerevisiae D5A was used for hexose conversion. In the second phase, the application of $S$. cerevisiae confirmed the efficient and stable utilization of glucose that overcome the relatively low ethanol yield of genetically modified strains (Li et al., 2010). Similarly, in another investigation, bioethanol was produced from corn stover by $S$. cerevisiae. The corn stover was first milled and pretreated with $2 \%$ w/w dilute $\mathrm{NaOH}$ solution followed by acidic hydrolysis at different concentrations of $\mathrm{H}_{2} \mathrm{SO}_{4}$. They reviewed the possibility of bioethanol production through a process of Separate Hydrolysis and Fermentation (SHF) and obtained $143.15 \mathrm{mg} / \mathrm{L}$ of ethanol under optimized studied conditions (Onoghwarite et al., 2016).

Corn stover may also be considered as an ideal fermentable substrate for biobutanol due to its sugar content and wide availability content and extensive availability (Baral et al., 2016). However, there are only a few studies that evaluated the corn stover application for large scale biobutanol production (Karimi Alavijeh and Karimi, 2019). For example, Baral and Shah, reported biobutanol production from corn stover by ABE fermentation using Clostridium species (Baral and Shah, 2014). Ding et al., also reported the potential of two types of treated Corn Stover (CS) hydrolysates for biobutanol production using $C$. saccharobutylicum strain. Fermentation of Hydrolysate I produced $7.4 \mathrm{~g} / \mathrm{L}$ of butanol with $0.21 \mathrm{~g}$ yield of total sugar and productivity $0.11 \mathrm{~g} / \mathrm{L} / \mathrm{h}$ while Hydrolysate II generated $7.9 \mathrm{~g} / \mathrm{L}$ of biobutanol with similar levels of ethanol and acetone with same productivity and yield (Ding et al., 2016).

\section{Palm Oil Mill Effluents (POME)}

POME is reported as industrial residue waste generated during palm oil milling activities and effective treatment is required for its disposal into water channels due to the presence of many pollutants (Hossain et al., 2017). Indonesia and Malaysia have been described as dominant producers of palm oil, followed by Nigeria, Thailand and Colombia. These countries together generate more than $93 \%$ of the world's palm oil production (Ohimain et al., 2013). One study in Malaysia reported that approximately 50 million tons of POME and 40 million tons of palm oil biomass are released annually from the palm oil industries. Being rich in cellulose (33-43\%), hemicelluloses (21-25\%), lignin (22-29\%) (Baharuddin et al., 2010) and high 
energy content, it has remarkable biotechnological value (Hossain et al., 2017). According to the literature, POME and other industrial residues of the palm oil industry has a high potential for biofuel production by Saccharolytic clostridia in ABE fermentation (Al-Shorgani et al., 2012a). Bioethanol was produced through spontaneous fermentation of POME with the addition of glucose and sugar cane bagasse with a high ethanol yield of $2.3 \%$ under optimized conditions (Wakil et al., 2013). More recently, Anggamulia et al., produced the highest amount of ethanol $0.102 \mathrm{~g} / \mathrm{L}$ from POME in a $12 \mathrm{~h}$ process using mixed bacterial culture (Anggamulia et al., 2020). Al-Shorgani et al., had successfully utilized raw POME to produce biobutanol by Clostridium saccharoperbutylacetonicum N1-4 (ATCC13564) in batch $\mathrm{ABE}$ fermentation. After optimization of the studied parameter, 0.9 and $2.09 \mathrm{~g} / \mathrm{L}$ of butanol and ABE were produced respectively (Al-Shorgani et al., 2015). In another study, POME was used as fermentable substrate for biogas production and found that $1.0 \mathrm{~m}^{3} \mathrm{POME}$ could generate about $28 \mathrm{~m}^{3}$ of biogas (Loh et al., 2017) in treatment plant under mesophilic $\left(30-40^{\circ} \mathrm{C}\right)$ conditions. Similarly, biogas was also produced from POME and Empty Fruit Bunches (EFB) by coupling liquid (L-AD) and Solid-State (SS-AD) anaerobic digestion processes (Suksong et al., 2020).

\section{De-oiled Rice Bran (DRB)}

De-oiled Rice Bran (DRB) is also a promising raw substance, which can be used as an inexpensive energy source. Al-Shorgani et al., has reported the use of treated rice bran and DRB for biobutanol production by $C$. saccharoperbutylacetonicum N1-4. Their scheme employed dilute $\mathrm{H}_{2} \mathrm{SO}_{4}$ and enzymatic hydrolysate followed by treating hydrolysate with XAD-4 resin, resulted in productivity of $0.1 \mathrm{~g} / \mathrm{L} / \mathrm{h}$ and a yield of 0.44 $\mathrm{g} / \mathrm{g}$ butanol. This study also showed the ability of XAD4 resin to remove inhibitors. They concluded that the extraction of oil from rice bran could improve butanol production by $88 \%$ (Al-Shorgani et al., 2012b). In another study, DRB was used as a renewable substrate for the fermentative production of hydrogen. Hydrolysis of DRB was done by dilute $\mathrm{H}_{2} \mathrm{SO}_{4}$ to obtain DRB hydrolysate as a substrate for hydrogen generation by the cultivation of new strain $C$. acetobutylicum YM1 in anaerobic fermentation. The verification experiment demonstrated that a cumulative hydrogen volume of $572.5 \mathrm{~mL}$ and a yield of $132.2 \mathrm{~mL} \mathrm{H}_{2} / \mathrm{g}$ was generated per total sugars consumed (Azman et al., 2016).

\section{Major Fermentable Compounds Present in Pyrolytic Oil}

Currently, the pyrolysis process has gained much attention as a faster and more efficient method for depolymerization of lignocellulosic biomass than acid hydrolysis or enzymatic hydrolysis. Pyrolysis is a thermal decomposition of biomass that occurs in the absence of oxygen to produce bio-oil, syngas and biochar (Islam et al., 2015; Jahirul et al., 2012). Pyrolysis oil, one of the main products of fast pyrolysis, commonly known as bio-oil, is a dark brown or dark green liquid, free-flowing and chemically complex with hundreds of compounds (Zhou et al., 2013). Mainly biooil contains pyrolytic lignin, water and a wide variety of organic compounds, i.e., sugars, organic acids, alcohols, aldehydes, ketones and phenolic components (Kim et al., 2015). Especially, pyrolytic sugars and organic acids are of particular interest as it can be utilized as carbon sources by microorganisms. Phenolic oligomers present in bio-oil can be upgraded to hydrocarbon, which can be further upgraded into drop-in fuels by using current infrastructure and petroleum refining technology (Mortensen et al., 2011).

Depending on the type of lignocellulosic material and the operating conditions, bio-oil can contain up to $33 \%$ ( $\mathrm{g} / \mathrm{g}$ biomass) of levoglucosan as major anhydrosugar, which can be easily hydrolyzed to glucose (Chi et al., 2013), thus acting as a most attractive fermentation substrate in the bio-oil. A significant amount of cellobiosan is frequently formed during fast pyrolysis, along with levoglucosan (Bai and Brown, 2014; Choi et al., 2014). Cellobiosan is converted to glucose by cleavage of the $\beta-1,4$ glycosidic bond in cellobiose. Linger et al., described the conversion of cellobiosan to fermentable carbon source by $\beta$-glucosidase-mediated hydrolysis for the first time (Linger et al., 2016). Acetic acid is another main compound present in the pyrolysis-based bio-oil, which is produced by deacetylation of hemicellulose and considered as an unwanted product due to its low heating value and corrosive property during storage, refining and transportation of bio-oil. Some of the major compounds of bio-oil are presented in Table 2 .

Table 2: Major compounds range (wt.\%) present in the bio-oil of lignocellulosic mass (Islam et al., 2015)

\begin{tabular}{ll}
\hline Compounds & Range (wt.\%) \\
\hline Levoglucosan & 30.5 \\
Formic acid & 9.1 \\
Acetic acid & $0.5-17$ \\
Propionic acid & 2.0 \\
Acetol & 7.4 \\
Methanol & 8.2 \\
1-hydroxy-2 butanone & 1.3 \\
Furfurals & $1.5-3.0$ \\
Phenol & 3.8 \\
Cresol & 2.5 \\
Ethylene glycol & $0.7-2.0$ \\
2- cyclopentene-1-one & $0.3-1.5$ \\
\hline
\end{tabular}


Bridgwater reported that there are many challenges that should be overcome while using raw bio-oil for fuel production (Bridgwater, 2012). Firstly, its moisture content is $15-35 \%(\mathrm{w} / \mathrm{w})$, which results in the low heating value of the product (Bridgwater et al., 1999). Secondly, being rich in carboxylic acids, acetic acid is most abundantly produced by lignin depolymerization, which is undesirable due to high corrosivity and low heating value (Aubin and Roy, 1990). Thirdly there are various inhibitors present in bio-oil that can strongly inhibit microbial growth in spite of fermentability of pyrolytic oil. To solve all these issues and simplify the bio-oil composition (Pollard et al., 2012), developed a bio-oil recovery system that fractionated bio-oil into five distinct Stage Fractions (SF) with distinctive physical and chemical properties, each fraction can be used for a different purpose. These fractions of bio-oil can be used as fermentable substrates in various fermentation processes. However, in literature, only the use of SF1 (rich in levoglucosan) and SF 5 (rich in acetic acid) are reported to date as fermentation substrates for biofuels production (Layton et al., 2011; Zhao et al., 2015).

\section{Utilization of Levoglucosan as a Fermentable Substrate}

SF1, containing levoglucosan as a major fermentable substrate, is of great interest for biological up-grading. In the past, researchers developed a process to separate pyrolytic sugars form phenolic compounds by using solvents, subsequently hydrolyzing the levoglucosan to glucose and then used fermentation set up to either produce fatty acids or ethanol (Lian et al., 2010). Similarly, Bennett et al. (2009) reported an increase of $216 \%$ yield of glucose by investigating optimal conditions for conversion of levoglucosan, attributing the high yield to cellobiosan and other oligomeric forms of cellulose present in the bio-oil fraction.

Unfortunately, it is reported that most workhorse biocatalysts are not capable of metabolizing levo-sugars directly. However, it can be converted to glucose by chemical catalysis or acid hydrolysis with additional processing steps. After hydrolysis, neutralization of the aqueous sugar-rich phase is required prior to fermentation, representing additional cost, so the utilization of organism that can metabolize levoglucosan directly was a prerequisite. This condition led to the identification of numerous microorganisms that could use levoglucosan as sole energy and carbon source (Jarboe et al., 2011). Many efforts have also been made to incorporate direct levoglucosan utilization pathways into other fermentation organisms by genetic engineering techniques. Hence by using genetic engineering tools, existing biocatalysts can easily be transformed into direct levoglucosan utilizers. For example, Layton et al., reported the utilization of levoglucosan with modification of present commercially available biocatalysts. They used levoglucosan as a substrate to produce ethanol by E. coli. Their scheme created an engineered ethanologenic $E$. coli by cloning the Levoglucosan Kinase (LGK) gene after codon optimization, resulting in not only the consumption of levoglucosan as a source of carbon and energy but also the production of ethanol (Layton et al., 2011). Table 3 has shown the fermentative use of levoglucosan by biocatalysts as conventional hexose sugars. Lian et al., described the direct utilization of levoglucosan as a carbon source by oleaginous yeasts Rhodotorula glutinis and Rhodotorula toruloides to produce microbial lipids after hydrolysis by LGK. Increment in unsaturated fatty acid was obtained by using levoglucosan as a carbon source. They suggested that the direct utilization of levoglucosan to support lipid accumulation was as good as using glucose in yeast cells (Lian et al., 2013). In one study, a strain of Pseudomonas putida KT2440 was genetically modified by heterologous integration of LGK from L. starkeyi to use levoglucosan as sole carbon and energy source. It was also shown that cellobiosan could be converted into levoglucosan and glucose with $\beta$-glucosidase enzymes and the modified strain of $P$. putida could grow on levoglucosan up to $60 \mathrm{~g} / \mathrm{L}$. Their study investigated the biological pathway for the coutilization of cellobiosan and levoglucosan, providing prospects for biological upgrading substrates derived from pyrolysis (Linger et al., 2016).

\section{Acetic Acid-Rich Fraction as Fermentable Substrates for Fermentation}

The SF5, which contains water and acetic acid as major components, can be removed from the bio-oil refinery for fuel production and can be used for other applications. Few researchers reported the use of SF5 as a fermentation substrate for biofuel production after excluding from bio-oil refinery and detoxification strategies (Pollard et al., 2012; Zhao et al., 2013). It has been demonstrated previously that some microorganisms can metabolize acetic acid to produce acetyl-CoA for the biosynthesis of fatty acids (Ratledge, 2004). A variety of oleaginous yeasts (Cryptococcus curvatus, Cryptococcus albidus, Yarrowia lipolytica (Christophe et al., 2012; Fontanille et al., 2012) and microalgae (Chlorella protothecoides) (Fei et al., 2015) can produce lipids by consuming acetic acid as single carbon source with high lipid content, i.e., $55 \%(\mathrm{~g} / \mathrm{g})$ of biomass. These oleaginous strains produced C:16 and C:18 fatty acids as main lipids, ready for biodiesel production. However, the use of acetic acid-rich bio-oil fraction (SF5) as fermentable substrates has some major challenges, such as the inhibition of cell growth by the toxic compounds present in bio-oil (Liang et al., 2013). 
Table 3: Biofuel chemicals produced from pyrolytic substrates by fermentation

\begin{tabular}{llll}
\hline Microorganism & Substrate & Product & Reference \\
\hline P. putida KT2440 & Levoglucosan & Polyhydroxyalkanoate & Linger et al. $(2016)$ \\
E. coli KO11 & Levoglucosan (SF1) & Ethanol & Layton et al. $(2011)$ \\
A. niger CBX 209, & Levoglucosan (SF1) & Citric acid & Zhuang and Zhang (2002) \\
C. reinhardtii & Acetic Acid (SF5) & Lipids & Liang et al. $(2013)$ \\
C. reinhardtii & Acetic Acid (SF5) & Lipids & Zhao et al. $(2013)$ \\
C. curvatus & Carboxylic acids & Lipids & Lian et al. $(2012)$ \\
\hline
\end{tabular}

Lian et al. (2012) reported the use of the SF5 phase by yeast fermentation after the successful removal of inhibitors of this fraction. Liang et al., also showed the feasibility of using SF5, derived from the fast pyrolysis of softwood for microalgae cultivation with the potential of lipid-based biofuel production. They documented an economical process based on activated carbon detoxification of bio-oil and complete purification for algal growth. Furthermore, by using the metabolic evolution of Chlamydomonas reinhardtii they were able to enhance algal tolerance to the toxicity of bio-oil. Their results concluded that the conversion of biomass into biofuel by fast pyrolysis-fermentation was a viable approach (Liang et al., 2013). In another study, Zhao et al., also reported the use of SF5 as a substrate for the growth of $C$. reinhardtii and lipid production. As this fraction of bio-oil is toxic, even at low concentration $(0.05 \% \mathrm{w})$, the growth of alga was inhibited. Therefore, they employed an alkali-based treatment $(\mathrm{NaOH})$ to reduce toxicity and enhance its fermentability by microalgae. It was observed adjusting the $\mathrm{pH}$ of SF5 fraction to 10 , improved the C. reinhardtii growth significantly even when the medium contained $4 \%$ (w) alkali-treated bio-oil fraction. By metabolic evolution of algal strains, it was found that metabolically evolved algal strain was able to grow on $5.5 \%$ of SF5 with $100 \%$ replacement of acetic acid in medium. So, in conclusion, alkali-based treatment was reported as an effective method for reducing bio-oil toxicity, thereby greatly enhancing the algae fermentability of bio-oil by removing hydroxymethyl furfural (HMF), furfural, phenolics and acetol from raw biooil fraction SF5 (Zhao et al., 2013). These studies suggested the fermentative use of levoglucosan and acetic acid (major fermentable components of bio-oil) by biocatalysts as conventional carbon and energy sources (shown in Table 3).

\section{Bioprocessing Technologies for Conversion of Biomass to Biofuels}

Researchers classified lignocellulosic biomass conversion technology into four major processes: (1) Separate Hydrolysis and Fermentation (SHF), (2) Simultaneous Saccharification and Fermentation (SSF), (3) Simultaneous Saccharification and Co-Fermentation (SSCF) and (4) Consolidated Bioprocessing (CBP) (Cheng et al., 2012; Zheng et al., 2009). Figure 3 shows the overview of all these 4 bioprocesses used for biofuel production. Cheng et al., applied separate hydrolysis and fermentation SHF process as well as sequential SHFSSF process to produce acetone, butanol and ethanol from pretreated bagasse and rice straw by an acclimated mixed bacterial microflora. They found that in the SHF process, the maximum butanol concentration, productivity and yield from bagasse was 2.29, 1.00 and $0.52 \mathrm{~mol}$ butanol/mol, reducing sugar, respectively. In comparison, for rice straw, it was 2.92, 1.41 and $0.51 \mathrm{~mol} \mathrm{butanol} / \mathrm{mol}$, reducing sugar, respectively. Hydrogen formation occurred during the $\mathrm{ABE}$ fermentation, with a titer and yield of 3.2-4.4 L/L and 1.8-2.2 mol reducing sugar, respectively. The overall productivity of SHF-SSF was higher, although the maximum butanol concentration obtained was similar for both substrates. Their study concluded that usage of rice straw as a feedstock could produce higher butanol yield than using bagasse, regardless of the type of fermentation processes used. Moreover, since $\mathrm{H}_{2}$ exists in the gas phase and the liquid fuels (ABE) have distinct boiling points $(56.2,117.7$ and $78.4^{\circ} \mathrm{C}$ respectively), separation of the four biofuels produced from the mixed culture would be relatively easy, leading to additional economic benefits arising from the simple downstream process (Cheng et al., 2012).

Ethanol production from lignocellulose is still expensive due to low final yield, requirements of additional nutrients and costly enzyme, feedback inhibition of enzymes by Separate Hydrolysis and Fermentation (SHF) process (Choudhary et al., 2016). In order to overcome the limitation of SHF, Simultaneous Saccharification and Co-Fermentation (SSCF) processes were recognized as a practical option for the conversion of xylose rich lignocellulose biomass into ethanol. But still, there is very little data and operating practices are documented in the literature. Koppram et al., reported ethanol production of $4 \%(\mathrm{w} / \mathrm{v})$ at a demo scale, which is an economical production of bioethanol. Their work utilized seven different recombinant strains of $S$. cerevisiae, which were able to utilize xylose from pretreated steam corncobs. Their findings suggested that enzymatic hydrolysis released optimal glucose for cultivation. Maintenance of low glucose concentrations throughout SSCF was necessary for the efficient conversion of xylose into ethanol. A combination of prefermentation with fed-batch SSCF, feeding of the substrate and enzymes produced 40 and $47 \mathrm{~g} / \mathrm{L}$ ethanol 
in Process Development Unit (PDU) at the demo scale (Koppram et al., 2013). In another study, Olofsson et al., reported that the cultivation of $S$. cerevisiae TMB3400 produced high ethanol concentration, which was achieved by a high amount of Water-Insoluble Solids (WIS) and solving the mixing problem as well as decreasing xylose uptake from steam-treated wheat straw in SSCF. Feeding of substrate allowed the addition of the maximum amount of WIS in process by preventing high viscosity while enzyme feeding would keep glucose concentration low which favored uptake of xylose resulting in higher conversion of xylose. So they suggested that in SSFC combination of substrate and enzyme addition could enhance the xylose uptake of yeast and increased ethanol yield from 40 to $50 \%$ as compared to substrate feeding only (Olofsson et al., 2010).

Gong et al., suggested Simultaneous Saccharification and Enhanced Lipid Production (SSELP) process that integrated the lignocellulosic biomass hydrolysis step and utilization of hydrolysate for lipid production. In their study, two-stage strategies were used; Firstly, cells were cultivated in a nutrient-rich medium and then cells were resuspended in a glucose solution without auxiliary nutrients. It was done for easier SSELP without sterilization as lignocellulosic hydrolysate contains hydrolytic enzymes. Their study found that cellulose and hemicellulose were utilized efficiently due to low glucose concentrations in culture. They concluded that SSELP enormously reduced the cost, time and appeared promising for lignocellulosic biomass conversion into fatty acid-based products (Gong et al., 2013).

Consolidated Bioprocessing (CBP) employs the process of integrating hydrolysis and fermentation steps into a single step, resulting in a significant reduction of steps in the refining process (Ali et al., 2016). The goal of CBP is to reduce four basic steps of biomass conversion to single one step in one bioreactor using a single microbe or microbial consortium, converting biomass to biofuels without adding saccharolytic enzymes (van Zyl et al., 2011). Fermentation of hexose and pentose sugars can be carried out in one single step (Amore and Faraco, 2012), offering low cost and enhanced efficiency of ethanol production from biomass in comparison to independent hydrolysis and fermentation steps (Schuster and Chinn, 2013). CBP can also minimize sugar losses by alleviating the need for glucose separation from lignin following the hydrolysis step (Olofsson et al., 2008).

Ideal microbes to carry out CBP with lignocellulosic substrates should have specific characteristics such as secretion of saccharifying enzymes, rapid lignocellulose biomass degradation, utilization of multiple sugars simultaneously, tolerant to final microbial metabolites and toxic lignin compounds (Vinuselvi and Lee, 2012). Thermophilic anaerobic bacteria, specifically belonging to the genus Clostridium and Caldicellulosiruptor have shown potential for CBP due to their efficient conversion of lignocellulosic substrate into ethanol (Resch et al., 2013). Industrially used microorganisms usually do not have cellulose degradation ability and also cannot metabolize other sugar in the presence of glucose, so researcher tackled this problem by using genetic engineered $E$. coli and yeast for co-metabolism of several sugars such as glucose, cellobiose, mannose, galactose and xylose (Vinuselvi and Lee, 2012). Similarly, Singh et al., isolated Clostridium sp. DBTIOC-C19 (cellulolytic thermophilic anaerobe) from cellulolytic enriched cultures obtained from the hot spring of a Himalayan, which showed a broad range spectrum for substrates. This strain successfully carried out a single-step conversion of lignocellulosic substrates to ethanol as a major fermentation product, including acetate and lactate. They also concluded that 3 different co-culture combination showed two-fold improve product formation than monoculture (Singh et al., 2017).

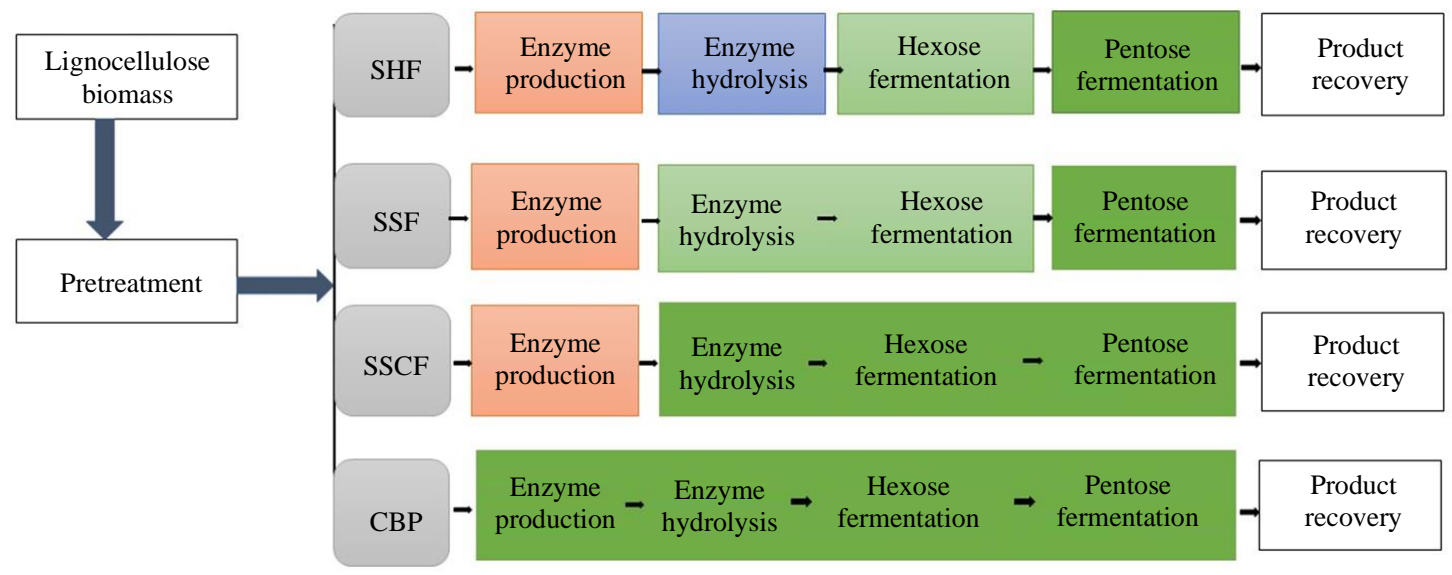

Fig. 3: Overview of bioprocessing technologies for the conversion of lignocellulosic biomass into useful bioproducts. SHF = Separate Hydrolysis and Fermentation; SSF = Simultaneous Saccharification and Fermentation; SSCF = Simultaneous Saccharification and co-fermentation: $\mathrm{CBP}=$ Consolidated Bioprocessing 
Tanimura et al., investigated the starch assimilating ability of 1,200 yeasts and found that oleaginous yeast Cryptococcus terricola could accumulate a significant amount of lipids by direct assimilation of soluble starch through CBP. Their study concluded that $C$. terricola JCM 24523 showed high lipid content $(61.96 \%)$ cultured in $5 \%$ starch medium for 10 days. Thus, due to yeast high lipid-accumulating ability, it can be used as an alternate source for biodiesel production. FAME analysis showed the ability of this strain to produce high proportions of C:16 and C:18 fatty acids, making it ideal for biodiesel production through CBP. Moreover, a system with no requirement for enzymatic hydrolysis would promote further development in applied production of biodiesel (Tanimura et al., 2014). Twostep CBP technology has been successfully used to produce ethanol $(3.7 \mathrm{~g} / \mathrm{L})$, butanol $(14.2 \mathrm{~g} / \mathrm{L})$, acetone $(5.4 \mathrm{~g} / \mathrm{L})$ and hydrogen by coculture of Enterococcus and clostridium using wheat straw as carbon substrate (Valdez-Vazquez et al., 2015). More recently (Pang et al., 2018) also employed CBP using corn straw to produce ethanol in an optimized process by cocultured Clostridium thermocellum and Thermoanaerobacterium thermosaccharolyticum.

Due to current advances in the synthetic biology design of various artificial microorganisms and better enzymes for CBP has been constructed, however still further research is needed to commercialize this process cost-effectively (Sommer et al., 2010). Many researchers constructed metagenomic libraries using genetic engineering to develop improved CBP microorganisms from various environments such as cow rumen, panda gut and soil microbes (Hess et al., 2011; Sommer et al., 2010; Zhu et al., 2011). An ideal CBP microbe, when constructed, would have a significant contribution to produce many microbial products efficiently.

\section{Major Challenges of Biofuels Production}

\section{Biomass Availability}

The main factors for biofuel production that must be highlighted are cheap, abundant and easy availability of feedstock, process integration and optimization and overall sustainability (Kokossis and Yang, 2010). The cost of feedstock contributes a significant amount in total operating cost, so easy and abundant availability to inexpensive feedstock supply is crucial for the sustainability of every biomass processing facility. Feedstocks based on lignocellulosic biomass are normally less expensive in comparison to other feedstocks, but high moisture and density can cause significant logistical challenges (Balan, 2014; Richard, 2010). The primary concern is to identify bio-products, particularly food, feed and other co-produced valuable chemicals and materials associated with energy for minimization of overall environmental issues and optimization of overall economics (Bioenergy, 2012).

\section{Biomass Conversion}

Lignocellulose is a complex structure which contains tough cell wall and lignin. Therefore, the degradation of the cell wall and separation of lignin is another major challenge (Zhu et al., 2015). Technologies for lignocellulosic fuels production are still not developed at pilot scales as compared to other fermentation processes for trans-esterification of biodiesel and corn ethanol (Balan et al., 2013). Conversion of lignocellulosic biomass to biofuel requires pretreatment for the efficient use of carbohydrates derived from starch and hemicellulose. Chemical pretreatment includes biomass hydrolysis using alkali, acid and ozone. Selection of suitable acid concentration is crucial for the industry since hemicellulose is often decomposed by acid resulting in degradation of sugars into inhibitors and can damage the equipment used. Hence traditional pretreatment method of biomass by acid hydrolysis has been substituted by biological saccharifying enzymes (Maiti et al., 2016). The cost of biofuel production can be controlled by reducing the lignin content in lignocellulosic feedstocks; it will improve saccharification efficiency through enzymatic hydrolysis. Generating lignocellulosic feedstock with lower lignin content by biotechnological methods and improved traits (tolerant to abiotic and biotic stresses) may benefit the developing countries by reducing their import of oil from middle-East countries and marginal farmers can be benefitted by an increase in economic growth (Kishore, 2017). So, there is a need to optimize the properties and composition of biomass along with imparting trait such as greater digestibility for easy bioconversion (Hughes et al., 2013).

\section{Microbial Lipid Production}

Microbial lipids have been suggested as a potential feedstock for biodiesel production for the past few years (Tang et al., 2015). Microbial lipids production requires more efficient and integrated processes for better technoeconomics of microbial lipid technology. High cost involved in microbial lipids production is a major hurdle for commercialization; thus, it is pivotal to design integrated processes apart from exploring sustainable raw materials such as lignocellulosic biomass. Commonly a batch culture should be designed in such a way that nutrient composition supports cell propagations and overcome the depletion of controlling nutrients for lipid accumulation simultaneously (Papanikolaou and Aggelis, 2011).

\section{Inhibitors of Pyrolysis Oil}

As it is mentioned in the above section that pyrolysis oil is a good source of many fermentable substrates such as sugars, carboxylic acid, hydroxy acetone and 
glycolaldehyde, which can be converted into ethanol, lipids and other useful chemicals through biological conversion (Islam et al., 2015). In spite of the fermentability of pyrolytic oil, various inhibitors present in bio-oil can strongly inhibit microbial growth. Though Pollard et al., fractionation system was good enough to separate different compounds of interest by fractionation system but still, these fractions contain fewer inhibitors that are toxic for microbial fermentation, so these fractions should be neutralized from toxic compounds for microbial growth. Some compounds in bio-oil that are identified, such as phenols and furfural, have been shown to inhibit the growth of microorganisms, while other unidentified compounds may also have inhibitory action for microbial growth (Zhao et al., 2015).

\section{Chemical-Based Detoxification}

Utilization of levoglucosan derived from bio-oil is another big challenge for microbial fermentation due to biological inhibitors such as HMF and butyric acid which are present in levoglucosan extracts aqueous phase (Chi et al., 2013; Fontanille et al., 2012). One of the major challenges for pyrolysis-based biorefinery is to find suitable detoxification strategy because toxic compounds in the bio-oil can inhibit cell growth and it is also possible that some of the detoxification strategies may reduce the yield of sugar available for fermentation (Rover et al., 2014). SF1 sugars are reported to contain contaminants such as acids, furans and phenol that can inhibit successful fermentation, so Rover et al., used different detoxification methods such as liquid-liquid extraction, ionic liquid, ionic resin and over liming to make pyrolytic sugar as fermentable substrate. $\mathrm{NaOH}$ over liming was found to be an optimal detoxification strategy, indicated by the maximum growth of $E$. coli and ethanol production (Rover et al., 2014). Similarly, Wang et al., also analyzed many detoxification strategies for the sugar-rich phase of bio-oil, such as activated carbon, extraction, air stripping, microbial digestion and adaptive evolution. They found $1 \%$ activated carbon as the best compound for complete removal of furfurals with no loss of glucose followed by solvent extraction. After detoxification of sugar-rich aqueous phase, it was used for ethanol fermentation by Saccharomyces pastorianus and concluded that utilization of the sugar-rich aqueous fraction of bio-oil was comparable to pure glucose utilization in medium (Wang et al., 2012). SF5 also contains many toxic inhibitors for microbial growth. Zhao et al., had investigated synergistic effects of alkaline $\mathrm{pH}$, high temperature and $\mathrm{Ca}(\mathrm{OH})_{2}$ for successful removal of furans, phenols, ketones, aldehydes, ethers, esters and alcohols. But they found a decrease in total fatty acid concentration by $C$. reinhardtii (Zhao et al., 2015).

Economic conversion of levo-sugar into biofuels is embedded with full of technical hurdles for commercialization. However, these limitations can be overcome by genetic engineering of microorganisms or microbial communities that can metabolize levoglucosan and also tolerate inhibitors present in biooil. It is more economical as compared to currently available conversion approaches that are based on the hydrolysis of levoglucosan prior to glucose fermentation (Claypool and Simmons, 2016).

\section{Microbial Detoxification}

Chemical detoxification could generate waste and utilize a large amount of reagents (Yang et al., 2014). To overcome this Yang et al., used biological detoxification strategy to inactivate the toxicity of inhibitors in the sugar-rich phase of bio-oil by using Phanerochaete chrysosporium, which can mineralize lignin and other related molecules. So, after the successful removal of toxins of sugars, it was fermented to citric acid by $A$. niger CBX-209 (Yang et al., 2014). Thus, the conversion of cellulose to citric acid was completed by both pyrolysis and bio-conversion technology. The bright aspect of microbial-based conversion is that it would not introduce any additional inhibitors to the aqueous fraction, but the limitation with this method is that only a few microorganisms are reported to have such a remarkable potential. Cupriavidus basilensis has shown the ability to consume phenol, furfural, HMF, toluene, dichlorophenol and benzene by maintaining glucose levels (Wierckx et al., 2010). The neutralization of these inhibitors may increase the capital cost of overall processing (Rover et al., 2014). These challenges could be overcome by the utilization of microorganisms that are tolerant to inhibitors; thus, pretreatment is not required.

In short, it is necessary to understand the limitations of every process and analyze the reliability of bioreactors with the development of suitable engineered workhorse to develop an efficient operating process. The determination of the detailed characteristics of bioproducts is also necessary. Although there is a continuous technologic improvement for cost reduction of biomass conversion, there is still a need to address the recalcitrant nature of biomass towards conversion processes and pretreatment methods. So, in the near future, advanced genetics improvement in the bio-conversion process and agronomy might help in the development of cost-effective biofuel production, which will guarantee more erudite biofuels application in vehicles and jet planes.

\section{Conclusive Remarks}

Biofuels are considered as a favorable alternative energy source as they are produced from sustainable energy crops. Currently, widely available lignocellulosic feedstock has attracted much attention as a renewable and sustainable source to produce biofuel via various 
biochemical and biological conversion. Pyrolysis-based conversion of biomass into biofuel and other value-added chemicals is another potential tool for commercial applications due to its socio-economic benefits. Genetic engineering of existing biocatalysts that can efficiently ferment lignocellulose, capable of utilizing pyrolytic sugars directly, as well as able to survive in the presence of inhibitors, should be addressed. Though there is a lot of research already being done on biofuel production, most of them are confined to lab-scale production, so further study is recommended to establish industrial-scale fermentation and suitable detoxification of pyrolysisbased oil to compete with conventional energy sources.

\section{Acknowledgment}

We thank the National Natural Science Foundation of China (Grants Nos. 31972851 and 31670064) and TaiShan Industrial Experts 508 Programme (No.tscy20160101) for funding this research.

\section{Author Contributions}

Tahira Naz and Yusuf Nazir: Conceptualization and review literature/data collection and writing draft.

Abu Bakr Ahmad Fazili: Review and editing and interpretation of data.

Kiren Mustafa: Editing and draw images and tables.

Xueyuan Bai: Provided funding and critical review.

Yuanda Song: Supervision and reviewing article.

\section{Competing Interests}

The authors declared no competing interests.

\section{References}

Al-Shorgani, N. K. N., Kalil, M. S., Ali, E., Hamid, A. A. and Yusoff, W. M. W. (2012a). The use of pretreated palm oil mill effluent for acetonebutanol-ethanol fermentation by Clostridium saccharoperbutylacetonicum N1-4. Clean Technologies and Environmental Policy, 14(5), 879-887.

Al-Shorgani, N. K. N., Kalil, M. S. and Yusoff, W. M. W. (2012b). Biobutanol production from rice bran and de-oiled rice bran by Clostridium saccharoperbutylacetonicum N1-4. Bioprocess and biosystems engineering, 35(5), 817-826.

Al-Shorgani, N. K. N., Shukor, H., Abdeshahian, P., Nazir, M. Y. M., Kalil, M. S., Hamid, A. A. and Yusoff, W. M. W. (2015). Process optimization of butanol production by Clostridium saccharoperbutylacetonicum N1-4 (ATCC 13564) using palm oil mill effluent in acetone-butanolethanol fermentation. Biocatalysis and agricultural biotechnology, 4(2), 244-249.
Ali, S. S., Nugent, B., Mullins, E. and Doohan, F. M. (2016). Fungal-mediated consolidated bioprocessing: the potential of Fusarium oxysporum for the lignocellulosic ethanol industry. AMB Express, 6(1), 13.

Ali, W., Rasul, R., Aziz, K., Bujag, A. and Shamsiah, D. S. (2012). Production of biocellulosic ethanol from wheat straw. Acta Polytechnica, 52(3).

Amore, A. and Faraco, V. (2012). Potential of fungi as category I Consolidated BioProcessing organisms for cellulosic ethanol production. Renewable and Sustainable Energy Reviews, 16(5), 3286-3301.

Anggamulia, M. I., Syafila, M., Handajani, M. and Gumilar, A. (2020). The potential bio-conversion of Palm Oil Mill Effluent (POME) as Bioethanol by steady-state anaerobic processes. In E3S Web of Conferences (Vol. 148, p. 02001). EDP Sciences.

Antal, M. J. (1983). Biomass pyrolysis: a review of the literature part 1-carbohydrate pyrolysis. In Advances in solar energy (pp. 61-111). Springer, Boston, MA.

Aubin, H. and Roy, C. (1990). Study on the corrosiveness op wood pyrolysis oils. Petroleum Science and Technology, 8(1), 77-86.

Azad, A. K., Yousuf, A., Ferdoush, A., Hasan, M. M., Karim, M. R. and Jahan, A. (2014). Production of microbial lipids from rice straw hydrolysates by lipomyces starkeyi for biodiesel synthesis. J Microb Biochem Technol S, 8(2).

Azman, N. F., Abdeshahian, P., Kadier, A., Al-Shorgani, N. K. N., ... and Kalil, M. S. (2016). Biohydrogen production from de-oiled rice bran as sustainable feedstock in fermentative process. international journal of hydrogen energy, 41(1), 145-156.

Baharuddin, A. S., Hock, L. S., Yusof, M. Z., Rahman, N. A. A., Shah, U. K., Hassan, M. A., ... and Shirai, Y. (2010). Effects of palm oil mill effluent (POME) anaerobic sludge from $500 \mathrm{~m} 3$ of closed anaerobic methane digested tank on pressed-shredded empty fruit bunch (EFB) composting process. African journal of Biotechnology, 9(16), 2427-2436.

Bai, X. and Brown, R. C. (2014). Modeling the physiochemistry of levoglucosan during cellulose pyrolysis. Journal of analytical and applied pyrolysis, 105, 363-368.

Bakker, R. R. C., Elbersen, H. W., Poppens, R. P. and Lesschen, J. P. (2013). Rice straw and wheat strawpotential feedstocks for the biobased economy. NL Agency.

Balan, V. (2014). Current challenges in commercially producing biofuels from lignocellulosic biomass. International Scholarly Research Notices, 2014.

Balan, V., Chiaramonti, D. and Kumar, S. (2013). Review of US and EU initiatives toward development, demonstration and commercialization of lignocellulosic biofuels. Biofuels, Bioproducts and Biorefining, 7(6), 732-759. 
Baral, N. R. and Shah, A. (2014). Microbial inhibitors: formation and effects on acetone-butanol-ethanol fermentation of lignocellulosic biomass. Applied microbiology and biotechnology, 98(22), 9151-9172.

Baral, N. R., Slutzky, L., Shah, A., Ezeji, T. C., Cornish, K. and Christy, A. (2016). Acetone-butanol-ethanol fermentation of corn stover: current production methods, economic viability and commercial use. FEMS microbiology letters, 363(6).

Batista, F. R. M., Lucchesi, K. W., Carareto, N. D. D., Costa, M. C. D. and Meirelles, A. J. A. (2018). Properties of microalgae oil from the species Chlorella protothecoides and its ethylic biodiesel. Brazilian Journal of Chemical Engineering, 35(4), 1383-1394.

Belal, E. B. (2013). Bioethanol production from rice straw residues. Brazilian Journal of Microbiology, 44(1), 225-234.

Bennett, N. M., Helle, S. S. and Duff, S. J. (2009). Extraction and hydrolysis of levoglucosan from pyrolysis oil. Bioresource technology, 100(23), 6059-6063.

Bensah, E. C. and Mensah, M. (2013). Chemical pretreatment methods for the production of cellulosic ethanol: technologies and innovations. International Journal of Chemical Engineering, 2013.

Bioenergy, I. E. A. (2012). Bio-based chemicals: Value added products from biorefineries. International Energy Agency, Wageningen, The Netherlands, 36.

Bolivar-Telleria, M., Turbay, C., Favarato, L., Carneiro, T., de Biasi, R. S., Fernandes, A. A. R., ... and Fernandes, P. (2018). Second-generation bioethanol from coconut husk. BioMed research international, 2018.

Branska, B., Fořtová, L., Dvořáková, M., Liu, H., Patakova, P., Zhang, J. and Melzoch, M. (2020). Chicken feather and wheat straw hydrolysate for direct utilization in biobutanol production. Renewable Energy, 145, 1941-1948.

Breuer, G., Lamers, P. P., Martens, D. E., Draaisma, R. B. and Wijffels, R. H. (2012). The impact of nitrogen starvation on the dynamics of triacylglycerol accumulation in nine microalgae strains. Bioresource Technology, 124, 217-226.

Bridgwater, A. V. (2012). Upgrading biomass fast pyrolysis liquids. Environmental Progress and Sustainable Energy, 31(2), 261-268.

Bridgwater, A. V., Meier, D. and Radlein, D. (1999). An overview of fast pyrolysis of biomass. Organic geochemistry, 30(12), 1479-1493.

Burton, T., Lyons, H., Lerat, Y., Stanley, M. and Rasmussen, M. B. (2009). A review of the potential of marine algae as a source of biofuel in Ireland.
Cheng, C. L., Che, P. Y., Chen, B. Y., Lee, W. J., Lin, C. Y. and Chang, J. S. (2012). Biobutanol production from agricultural waste by an acclimated mixed bacterial microflora. Applied Energy, 100, 3-9.

Chi, Z., Rover, M., Jun, E., Deaton, M., Johnston, P., Brown, R. C., ... and Jarboe, L. R. (2013). Overliming detoxification of pyrolytic sugar syrup for direct fermentation of levoglucosan to ethanol. Bioresource technology, 150, 220-227.

Choi, Y. S., Johnston, P. A., Brown, R. C., Shanks, B. H. and Lee, K. H. (2014). Detailed characterization of red oak-derived pyrolysis oil: Integrated use of GC, HPLC, IC, GPC and Karl-Fischer. Journal of Analytical and Applied Pyrolysis, 110, 147-154.

Choudhary, J., Singh, S. and Nain, L. (2016). Thermotolerant fermenting yeasts for simultaneous saccharification fermentation of lignocellulosic biomass. Electronic Journal of Biotechnology, 21, 82-92.

Christophe, G., Deo, J. L., Kumar, V., Nouaille, R., Fontanille, P. and Larroche, C. (2012). Production of oils from acetic acid by the oleaginous yeast Cryptococcus curvatus. Applied biochemistry and biotechnology, 167(5), 1270-1279.

Clarence, O., (2016). Assessment of quantity of coconut waste generated and management in the Kumasi Metropolis, Ghana. Kwame Nkrumah University of Science and Technology.

Claypool, J. T. and Simmons, C. W. (2016). Hybrid thermochemical/biological processing: The economic hurdles and opportunities for biofuel production from bio-oil. Renewable Energy, 96, 450-457.

Dahadha, S., Amin, Z., Bazyar Lakeh, A. A. and Elbeshbishy, E. (2017). Evaluation of different pretreatment processes of lignocellulosic biomass for enhanced biomethane production. Energy and Fuels, 31(10), 10335-10347.

Demirbas, A. (2008). Biofuels sources, biofuel policy, biofuel economy and global biofuel projections. Energy conversion and management, 49(8), 2106-2116.

Ding, J. C., Xu, G. C., Han, R. Z. and Ni, Y. (2016). Biobutanol production from corn stover hydrolysate pretreated with recycled ionic liquid by Clostridium saccharobutylicum DSM 13864. Bioresource technology, 199, 228-234.

EPA, (2010). Finalizes regulations for the national renewable fuel standard program for 2010 and beyond. Office of Transportation and Air Quality, US Environmental Protection Agency.

Esterhuizen, D. (2013). Sugar annual: Republic of South Africa. Global Agricultural Information Network, United States, Department of Agriculture. 
Evcan, E. and Tari, C. (2015). Production of bioethanol from apple pomace by using cocultures: Conversion of agro-industrial waste to value added product. Energy, 88, 775-782.

Fairley, P. (2011). Introduction: next generation biofuels. Nature, 474(7352), S2-S5.

Fei, Q., Fu, R., Shang, L., Brigham, C. J. and Chang, H. N. (2015). Lipid production by microalgae Chlorella protothecoides with volatile fatty acids (VFAs) as carbon sources in heterotrophic cultivation and its economic assessment. Bioprocess and Biosystems Engineering, 38(4), 691-700.

Ferreira, S., Duarte, A. P., Ribeiro, M. H., Queiroz, J. A. and Domingues, F. C. (2009). Response surface optimization of enzymatic hydrolysis of Cistus ladanifer and Cytisus striatus for bioethanol production. Biochemical Engineering Journal, 45(3), 192-200.

Fontanille, P., Kumar, V., Christophe, G., Nouaille, R. and Larroche, C. (2012). Bioconversion of volatile fatty acids into lipids by the oleaginous yeast Yarrowia lipolytica. Bioresource technology, 114, 443-449.

Frankel, E. N., Satué-Gracia, T., Meyer, A. S. and German, J. B. (2002). Oxidative stability of fish and algae oils containing long-chain polyunsaturated fatty acids in bulk and in oil-in-water emulsions. Journal of Agricultural and Food Chemistry, 50(7), 2094-2099.

Galbe, M. and Zacchi, G. (2012). Pretreatment: the key to efficient utilization of lignocellulosic materials. Biomass and bioenergy, 46, 70-78.

Gaurav, N., Sivasankari, S., Kiran, G. S., Ninawe, A. and Selvin, J. (2017). Utilization of bioresources for sustainable biofuels: a review. Renewable and Sustainable Energy Reviews, 73, 205-214.

Gonçalves, F. A., Ruiz, H. A., dos Santos, E. S., Teixeira, J. A. and de Macedo, G. R. (2015). Bioethanol production from coconuts and cactus pretreated by autohydrolysis. Industrial Crops and Products, 77, 1-12.

Gonçalves, F. A., Ruiz, H. A., da Costa Nogueira, C., dos Santos, E. S., Teixeira, J. A. and de Macedo, G. R. (2014). Comparison of delignified coconuts waste and cactus for fuel-ethanol production by the simultaneous and semi-simultaneous saccharification and fermentation strategies. Fuel, 131, 66-76.

Gong, Z., Shen, H., Wang, Q., Yang, X., Xie, H. and Zhao, Z. K. (2013). Efficient conversion of biomass into lipids by using the simultaneous saccharification and enhanced lipid production process. Biotechnology for biofuels, 6(1), 36.

Guldhe, A., Singh, B., Renuka, N., Singh, P., Misra, R. and Bux, F. (2017). Bioenergy: a sustainable approach for cleaner environment. In Phytoremediation potential of bioenergy plants (pp. 47-62). Springer, Singapore.
Haykiri-Acma, H. and Yaman, S. (2010). Interaction between biomass and different rank coals during copyrolysis. Renewable energy, 35(1), 288-292.

Hess, J. R., Kenney, K. L., Wright, C. T., Perlack, R. and Turhollow, A. (2009). Corn stover availability for biomass conversion: situation analysis. Cellulose, 16(4), 599-619.

Hess, M., Sczyrba, A., Egan, R., Kim, T. W., Chokhawala, H., Schroth, G., ... and Mackie, R. I. (2011). Metagenomic discovery of biomassdegrading genes and genomes from cow rumen. Science, 331(6016), 463-467.

Hossain, N., Zaini, J. H. and Mahlia, T. M. I. (2017). A review of bioethanol production from plant-based waste biomass by yeast fermentation. International Journal of Technology.

Hughes, S. R., Gibbons, W. R., Moser, B. R. and Rich, J. O. (2013). Sustainable multipurpose biorefineries for third-generation biofuels and value-added coproducts. Biofuels-Economy, Environment and Sustainability, 245-267.

Islam, Z. U., Zhisheng, Y., Dongdong, C. and Hongxun, Z. (2015). Microbial conversion of pyrolytic products to biofuels: a novel and sustainable approach toward second-generation biofuels. Journal of industrial microbiology and biotechnology, 42(12), 1557-1579.

Jahirul, M. I., Rasul, M. G., Chowdhury, A. A. and Ashwath, N. (2012). Biofuels production through biomass pyrolysis - a technological review. Energies, 5(12), 4952-5001.

Jarboe, L. R., Wen, Z., Choi, D. and Brown, R. C. (2011). Hybrid thermochemical processing: fermentation of pyrolysis-derived bio-oil. Applied microbiology and biotechnology, 91(6), 1519.

Karimi Alavijeh, M. and Karimi, K., (2019). Biobutanol production from corn stover in the US. Industrial Crops and Products, 129, 641-653.

Karlsson, H., Ahlgren, S., Sandgren, M., Passoth, V., Wallberg, O. and Hansson, P. A. (2016). A systems analysis of biodiesel production from wheat straw using oleaginous yeast: process design, mass and energy balances. Biotechnology for biofuels, 9(1), 229.

Kartha, S. and Larson, E. D. (2000). Bioenergy primer: Modernised biomass energy for sustainable development. UNDP.

Kim, E. M., Um, Y., Bott, M. and Woo, H. M. (2015). Engineering of Corynebacterium glutamicum for growth and succinate production from levoglucosan, a pyrolytic sugar substrate. FEMS Microbiology Letters, 362(19), fnv161.

Kishore, N. S., (2017). Lignocellulosic BiofuelsChallenges and Potentials. Int $\mathrm{J}$ Pharma Bio Sci, 8(1), 376-81. 
Klinke, H. B., Olsson, L., Thomsen, A. B. and Ahring, B. K. (2003). Potential inhibitors from wet oxidation of wheat straw and their effect on ethanol production of Saccharomyces cerevisiae: wet oxidation and fermentation by yeast. Biotechnology and bioengineering, 81(6), 738-747.

Kokossis, A. C. and Yang, A. (2010). On the use of systems technologies and a systematic approach for the synthesis and the design of future biorefineries. Computers and Chemical Engineering, 34(9), 1397-1405.

Koppram, R., Nielsen, F., Albers, E., Lambert, A., Wännström, S., Welin, L., ... and Olsson, L. (2013). Simultaneous saccharification and co-fermentation for bioethanol production using corncobs at lab, PDU and demo scales. Biotechnology for Biofuels, 6(1), 2.

Kraiphanont, A., Nunes, B. and Bennett, D. (2016). The main criteria of biomass selection for energy generation in Brazil.

Lam, M. K., Lee, K. T. and Mohamed, A. R. (2010). Homogeneous, heterogeneous and enzymatic catalysis for transesterification of high free fatty acid oil (waste cooking oil) to biodiesel: a review. Biotechnology advances, 28(4), 500-518.

Layton, D. S., Ajjarapu, A., Choi, D. W. and Jarboe, L. R. (2011). Engineering ethanologenic Escherichia coli for levoglucosan utilization. Bioresource technology, 102(17), 8318-8322.

Li, A., Antizar-Ladislao, B. and Khraisheh, M. (2007). Bioconversion of municipal solid waste to glucose for bio-ethanol production. Bioprocess and Biosystems Engineering, 30(3), 189-196.

Li, X., Kim, T. H. and Nghiem, N. P. (2010). Bioethanol production from corn stover using aqueous ammonia pretreatment and two-phase simultaneous saccharification and fermentation (TPSSF). Bioresource technology, 101(15), 5910-5916.

Lian, J., Chen, S., Zhou, S., Wang, Z., O’Fallon, J., Li, C. Z. and Garcia-Perez, M. (2010). Separation, hydrolysis and fermentation of pyrolytic sugars to produce ethanol and lipids. Bioresource technology, 101(24), 9688-9699.

Lian, J., Garcia-Perez, M. and Chen, S. (2013). Fermentation of levoglucosan with oleaginous yeasts for lipid production. Bioresource technology, 133, 183-189.

Lian, J., Garcia-Perez, M., Coates, R., Wu, H. and Chen, S. (2012). Yeast fermentation of carboxylic acids obtained from pyrolytic aqueous phases for lipid production. Bioresource technology, 118, 177-186.

Liang, Y., Zhao, X., Chi, Z., Rover, M., Johnston, P., Brown, R., ... and Wen, Z. (2013). Utilization of acetic acid-rich pyrolytic bio-oil by microalga Chlamydomonas reinhardtii: reducing bio-oil toxicity and enhancing algal toxicity tolerance. Bioresource technology, 133, 500-506.
Liew, F., Martin, M. E., Tappel, R. C., Heijstra, B. D., Mihalcea, C. and Köpke, M. (2016). Gas fermentation - a flexible platform for commercial scale production of low-carbon-fuels and chemicals from waste and renewable feedstocks. Frontiers in microbiology, 7, 694.

Linger, J. G., Hobdey, S. E., Franden, M. A., Fulk, E. M. and Beckham, G. T. (2016). Conversion of levoglucosan and cellobiosan by Pseudomonas putida KT2440. Metabolic engineering communications, 3, 24-29.

Liu, C., van der Heide, E., Wang, H., Li, B., Yu, G. and $\mathrm{Mu}, \quad \mathrm{X}$. (2013). Alkaline twin-screw extrusion pretreatment for fermentable sugar production. Biotechnology for biofuels, 6(1), 97.

Loh, S. K., Nasrin, A., Mohamad Azri, S., Nurul Adela, B. and Muzzammil, N. (2017). Biogas capture-A means of reducing greenhouse gas emissions from palm oil mill effluent. Oil Palm Bulletin, 75, 27-36.

Maiti, S., Sarma, S. J., Brar, S. K., Le Bihan, Y., Drogui, P., Buelna, G. and Verma, M. (2016). Agroindustrial wastes as feedstock for sustainable bioproduction of butanol by Clostridium beijerinckii. Food and Bioproducts Processing, 98, 217-226.

Malik, A., Lenzen, M., Ralph, P. J. and Tamburic, B. (2015). Hybrid life-cycle assessment of algal biofuel production. Bioresource technology, 184, 436-443.

Mata, G. and Savoie, J. M., (2005). Wheat Straw. In: Mushroom Growers Handbook 2 - Shiitake Cultivation, (pp: 105-109).

Mishra, S. B. (2018). Nanoadditives: Propitious Alternative For Increase Biofuel Performance. In Green Nanotechnology for Biofuel Production (pp. 63-78). Springer, Cham.

Mohan, D., Pittman Jr, C. U. and Steele, P. H. (2006). Pyrolysis of wood/biomass for bio-oil: a critical review. Energy and fuels, 20(3), 848-889.

Mortensen, P. M., Grunwaldt, J. D., Jensen, P. A., Knudsen, K. G. and Jensen, A. D. (2011). A review of catalytic upgrading of bio-oil to engine fuels. Applied Catalysis A: General, 407(1-2), 1-19.

Munasinghe, P. C. and Khanal, S. K. (2010). Biomassderived syngas fermentation into biofuels: opportunities and challenges. Bioresource technology, 101(13), 5013-5022.

Naik, S. N., Goud, V. V., Rout, P. K. and Dalai, A. K. (2010). Production of first and second generation biofuels: a comprehensive review. Renewable and sustainable energy reviews, 14(2), 578-597.

Nazir, Y., Halim, H., Prabhakaran, P., Ren, X., Naz, T., Mohamed, H., ... and Song, Y. (2020). Different Classes of Phytohormones Act Synergistically to Enhance the Growth, Lipid and DHA Biosynthetic Capacity of Aurantiochytrium sp. SW1. Biomolecules, 10(5), 755. 
Nigam, J. N. (2001). Ethanol production from wheat straw hemicellulose hydrolysate by Pichia stipitis. Journal of biotechnology, 87(1), 17-27.

Nigam, P. S. and Singh, A. (2011). Production of liquid biofuels from renewable resources. Progress in energy and combustion science, 37(1), 52-68.

Obeng, G. Y., Amoah, D. Y., Opoku, R., Sekyere, C. K., Adjei, E. A. and Mensah, E. (2020). Coconut Wastes as Bioresource for Sustainable Energy: Quantifying Wastes, Calorific Values and Emissions in Ghana. Energies, 13(9), 2178.

Ohimain, E. I., Izah, S. C. and Fawari, A. D. (2013). Quality assessment of crude palm oil produced by semi-mechanized processor in Bayelsa state, Nigeria. Discourse Journal of Agriculture and Food Sciences, 1(11), 34-46.

Ohimor, O., Ndirika, V. and Akachukwu Ben, E., (2016). Bioethanol production from corn stover using Saccharomyces cerevisiae. Int. J. Scientific Eng. Res.

Ojeda, K., Ávila, O., Suárez, J. and Kafarov, V. (2011). Evaluation of technological alternatives for process integration of sugarcane bagasse for sustainable biofuels production-Part 1. Chemical Engineering Research and Design, 89(3), 270-279.

Olofsson, K., Bertilsson, M. and Lidén, G. (2008). A short review on $\mathrm{SSF}$-an interesting process option for ethanol production from lignocellulosic feedstocks. Biotechnology for biofuels, 1(1), 7.

Olofsson, K., Palmqvist, B. and Lidén, G. (2010). Improving simultaneous saccharification and cofermentation of pretreated wheat straw using both enzyme and substrate feeding. Biotechnology for biofuels, 3(1), 17.

Onoghwarite, O. E., Obiora, N. V., Ben, E. A. and Moses, N. O. E. (2016). Bioethanol production from corn stover using Saccharomyces cerevisiae. International Journal of Engineering Science, 7(8).

Pandey, V. C., Bajpai, O. and Singh, N. (2016). Energy crops in sustainable phytoremediation. Renewable and Sustainable Energy Reviews, 54, 58-73.

Pang, J., Hao, M., Li, Y., Liu, J., Lan, H., Zhang, Y., ... and Liu, Z. (2018). Consolidated Bioprocessing Using Clostridium thermocellum and Thermoanaerobacterium thermosaccharolyticum Co-culture for Enhancing Ethanol Production from Corn Straw. BioResources, 13(4), 8209-8221.

Papanikolaou, S. and Aggelis, G., (2011). "Lipids of oleaginous yeasts. Part I: Biochemistry of single cell oil production." European Journal of Lipid Science and Technology 113.8 (2011): 1031-1051.

Patra, J., Basu, A., Mishra, A. and Dhal, N. K. (2017). Bioconversion of Municipal Solid Wastes for Bioethanol Production. Biosciences Biotechnology Research Asia, 14(3), 1151-1157.
Patwardhan, P. R., Dalluge, D. L., Shanks, B. H. and Brown, R. C. (2011). Distinguishing primary and secondary reactions of cellulose pyrolysis. Bioresource technology, 102(8), 5265-5269.

Pollard, A. S., Rover, M. R. and Brown, R. C. (2012). Characterization of bio-oil recovered as stage fractions with unique chemical and physical properties. Journal of Analytical and Applied Pyrolysis, 93, 129-138.

Qi, G., Xiong, L., Li, H., Huang, Q., Luo, M., Tian, L., ... and Chen, X. (2019). Hydrotropic pretreatment on wheat straw for efficient biobutanol production. Biomass and Bioenergy, 122, 76-83.

Rajesh, A. R. R., Rajesh, R., Rajesh, E. M., Rajendran, R. and Jeyachandran, S. (2008). Production of bio-ethanol from cellulosic cotton waste through microbial extracellular enzymatic hydrolysis and fermentation. Electronic journal of environmental, agricultural and food chemistry, 7(6), 2948-2958.

Ranisau, J., Ranisau, J., Ogbe, E., Trainor, A., Barbouti, M., Elsholkami, M., Elkamel, A. and Fowler, M. (2017). Optimization of biofuel production from corn stover under supply uncertainty in Ontario. Biofuel Research Journal, 4(4), 721-729.

Ratledge, C. (2004). Fatty acid biosynthesis in microorganisms being used for single cell oil production. Biochimie, 86(11), 807-815.

Reginatto, V. and Antônio, R. V. (2015). Fermentative hydrogen production from agroindustrial lignocellulosic substrates. Brazilian Journal of Microbiology, 46(2), 323-335.

Resch, M. G., Donohoe, B. S., Baker, J. O., Decker, S. R., Bayer, E. A., Beckham, G. T. and Himmel, M. E. (2013). Fungal cellulases and complexed cellulosomal enzymes exhibit synergistic mechanisms in cellulose deconstruction. Energy and Environmental Science, 6(6), 1858-1867.

Richard, T. L. (2010). Challenges in scaling up biofuels infrastructure. Science, 329(5993), 793-796.

Rover, M. R., Johnston, P. A., Jin, T., Smith, R. G., Brown, R. C. and Jarboe, L. (2014). Production of clean pyrolytic sugars for fermentation. ChemSusChem, 7(6), 1662-1668.

Ryckebosch, E., Muylaert, K. and Foubert, I. (2012). Optimization of an analytical procedure for extraction of lipids from microalgae. Journal of the American Oil Chemists' Society, 89(2), 189-198.

Sangkharak, K., Chookhun, K., Numreung, J. and Prasertsan, P. (2019). Utilization of coconut meal, a waste product of milk processing, as a novel substrate for biodiesel and bioethanol production. Biomass Conversion and Biorefinery, 1-12.

Sannigrahi, P. and Ragauskas, A. J. (2011). Characterization of fermentation residues from the production of bio-ethanol from lignocellulosic feedstocks. Journal of Biobased Materials and Bioenergy, 5(4), 514-519. 
Schuster, B. G. and Chinn, M. S. (2013). Consolidated bioprocessing of lignocellulosic feedstocks for ethanol fuel production. BioEnergy Research, 6(2), 416-435.

Seidl, P. R. and Goulart, A. K. (2016). Pretreatment processes for lignocellulosic biomass conversion to biofuels and bioproducts. Current Opinion in Green and Sustainable Chemistry, 2, 48-53.

Shah, T. A. and Tabassum, R. (2018). Enhancing biogas production from lime soaked corn cob residue. Int. J. Renew. Energy Res, 8, 761-766.art, A. K. (2016). Pretreatment processes for lignocellulosic biomass conversion to biofuels and bioproducts. Current Opinion in Green and Sustainable Chemistry, 2, 4853.

Shen, Y., Jarboe, L., Brown, R. and Wen, Z. (2015). A thermochemical-biochemical hybrid processing of lignocellulosic biomass for producing fuels and chemicals. Biotechnology advances, 33(8), 17991813.

Shetty, D. J., Kshirsagar, P., Tapadia-Maheshwari, S., Lanjekar, V., Singh, S. K. and Dhakephalkar, P. K. (2017). Alkali pretreatment at ambient temperature: A promising method to enhance biomethanation of rice straw. Bioresource technology, 226, 80-88.

Singh, B., Guldhe, A., Singh, P., Singh, A., Rawat, I. and Bux, F. (2015). Sustainable production of biofuels from microalgae using a biorefinary approach. In Applied environmental biotechnology: Present scenario and future trends (pp. 115-128). Springer, New Delhi.

Singh, N., Mathur, A. S., Tuli, D. K., Gupta, R. P., Barrow, C. J. and Puri, M. (2017). Cellulosic ethanol production via consolidated bioprocessing by a novel thermophilic anaerobic bacterium isolated from a Himalayan hot spring. Biotechnology for biofuels, 10(1), 1-18.

Singh, P., Kumari, S., Guldhe, A., Misra, R., Rawat, I. and Bux, F. (2016). Trends and novel strategies for enhancing lipid accumulation and quality in microalgae. Renewable and Sustainable Energy Reviews, 55, 1-16.

Sissine, F. (2010). Renewable Fuel Standard Program (RFS2) Regulatory Impact Analysis. Assessment and Standards Division, Office of Transportation and Air Quality.

Smuga-Kogut, M., Wnuk, A. D., Zgórska, K., Kubiak, M. S., Wojdalski, J., Kupczyk, A., ... and Luberański, A. (2015). Production of ethanol from wheat straw. Polish Journal of Chemical Technology, 17(3), 89-94.

Sommer, M. O., Church, G. M. and Dantas, G. (2010). A functional metagenomic approach for expanding the synthetic biology toolbox for biomass conversion. Molecular systems biology, 6(1), 360.
Suksong, W., Tukanghan, W., Promnuan, K., Kongjan, P., Reungsang, A., Insam, H. and Sompong, O. (2020). Biogas production from palm oil mill effluent and empty fruit bunches by coupled liquid and solid-state anaerobic digestion. Bioresource technology, 296, 122304.

Sulaiman, S., Raman, A. A. A. and Aroua, M. K. (2010, November). Coconut waste as a source for biodiesel production. In 2010 2nd International Conference on Chemical, Biological and Environmental Engineering (pp. 254-256). IEEE.

Takano, M. and Hoshino, K. (2018). Bioethanol production from rice straw by simultaneous saccharification and fermentation with statistical optimized cellulase cocktail and fermenting fungus. Bioresources and Bioprocessing, 5(1), 16.

Talebnia, F., Karakashev, D. and Angelidaki, I. (2010). Production of bioethanol from wheat straw: an overview on pretreatment, hydrolysis and fermentation. Bioresource technology, 101(13), 4744-4753.

Tang, X., Chen, H., Chen, Y. Q., Chen, W., Garre, V., Song, Y. and Ratledge, C. (2015). Comparison of biochemical activities between high and low lipidproducing strains of Mucor circinelloides: an explanation for the high oleaginicity of strain WJ11. PloS one, 10(6), e0128396.

Tanimura, A., Takashima, M., Sugita, T., Endoh, R., Kikukawa, M., Yamaguchi, S., ... and Shima, J. (2014). Cryptococcus terricola is a promising oleaginous yeast for biodiesel production from starch through consolidated bioprocessing. Scientific reports, 4, 4776.

Tishler, Y., Samach, A., Rogachev, I., Elbaum, R. and Levy, A. A. (2015). Analysis of wheat straw biodiversity for use as a feedstock for biofuel production. BioEnergy Research, 8(4), 1831-1839.

Valdez-Vazquez, I., Pérez-Rangel, M., Tapia, A., Buitrón, G., Molina, C., Hernández, G. and Amaya-Delgado, L. (2015). Hydrogen and butanol production from native wheat straw by synthetic microbial consortia integrated by species of Enterococcus and Clostridium. Fuel, 159, 214-222.

van Zyl, W. H., den Haan, R. and la Grange, D. C. (2011). Developing organisms for consolidated bioprocessing of biomass to ethanol. Biofuel production-recent developments and prospects.

Vassilev, S. V. and Vassileva, C. G. (2016). Composition, properties and challenges of algae biomass for biofuel application: an overview. Fuel, 181, 1-33.

Vinuselvi, P. and Lee, S. K. (2012). Engineered Escherichia coli capable of co-utilization of cellobiose and xylose. Enzyme and microbial technology, 50(1), 1-4. 
Wainaina, S., Horváth, I. S. and Taherzadeh, M. J. (2018). Biochemicals from food waste and recalcitrant biomass via syngas fermentation: a review. Bioresource technology, 248, 113-121.

Wakil, S. M., Fasiku, S. A., Adelabu, A. B. and Onilude, A. A. (2013). Production of bioethanol from spontaneous fermentation of palm oil mill effluent (POME). Researcher, 5(2), 28-35.

Wang, H., Livingston, D., Srinivasan, R., Li, Q., Steele, P. and $\mathrm{Yu}, \mathrm{F}$. (2012). Detoxification and fermentation of pyrolytic sugar for ethanol production. Applied biochemistry and biotechnology, 168(6), 1568-1583.

Wang, Y., Fan, C., Hu, H., Li, Y., Sun, D., Wang, Y. and Peng, L. (2016). Genetic modification of plant cell walls to enhance biomass yield and biofuel production in bioenergy crops. Biotechnology advances, 34(5), 997-1017.

Wei, Z., Zeng, G., Huang, F., Kosa, M., Sun, Q., Meng, X., ... and Ragauskas, A. J. (2015). Microbial lipid production by oleaginous Rhodococci cultured in lignocellulosic autohydrolysates. Applied microbiology and biotechnology, 99(17), 7369-7377.

Wierckx, N., Koopman, F., Bandounas, L., De Winde, J. H. and Ruijssenaars, H. J. (2010). Isolation and characterization of Cupriavidus basilensis HMF14 for biological removal of inhibitors from lignocellulosic hydrolysate. Microbial biotechnology, 3(3), 336-343.

WBA, (2017). WBA global bioenergy statistics 2017. World Bioenergy Association Global Bioenergy Statistics.

Yang, Z., Bai, Z., Sun, H., Yu, Z., Li, X., Guo, Y. and Zhang, H. (2014). Biomass pyrolysis liquid to citric acid via 2-step bioconversion. Microbial cell factories, 13(1), 182.

Zanotti, M., Ruan, Z., Bustamente, M., Liu, Y. and Liao, W. (2016). A sustainable lignocellulosic biodiesel production integrating solar-and bio-power generation. Green Chemistry, 18(18), 5059-5068.
Zhao, X., Chi, Z., Rover, M., Brown, R., Jarboe, L. and Wen, Z. (2013). Microalgae fermentation of acetic acid - rich pyrolytic bio - oil: Reducing bio - oil toxicity by alkali treatment. Environmental Progress and Sustainable Energy, 32(4), 955-961.

Zhao, X., Davis, K., Brown, R., Jarboe, L. and Wen, Z. (2015). Alkaline treatment for detoxification of acetic acid-rich pyrolytic bio-oil for microalgae fermentation: Effects of alkaline species and the detoxification mechanisms. Biomass and Bioenergy, 80, 203-212.

Zheng, Y., Pan, Z. and Zhang, R. (2009). Overview of biomass pretreatment for cellulosic ethanol production. International journal of agricultural and biological engineering, 2(3), 51-68.

Zhou, S., Mourant, D., Lievens, C., Wang, Y., Li, C. Z. and Garcia-Perez, M. (2013). Effect of sulfuric acid concentration on the yield and properties of the biooils obtained from the auger and fast pyrolysis of Douglas Fir. Fuel, 104, 536-546.

Zhu, J. Y., Chandra, M. S., Gu, F., Gleisner, R., Reiner, R., Sessions, J., ... and Anderson, D. (2015). Using sulfite chemistry for robust bioconversion of Douglas-fir forest residue to bioethanol at high titer and lignosulfonate: a pilot-scale evaluation. Bioresource Technology, 179, 390-397.

Zhu, L., Wu, Q., Dai, J., Zhang, S. and Wei, F. (2011). Evidence of cellulose metabolism by the giant panda gut microbiome. Proceedings of the National Academy of Sciences, 108(43), 17714-17719.

Zhuang, X. and Zhang, H. (2002). Identification, characterization of levoglucosan kinase and cloning and expression of levoglucosan kinase cDNA from Aspergillus niger CBX-209 in Escherichia coli. Protein expression and purification, 26(1), 71-81. 